\title{
Development of the Logical Mathematical Reasoning through the Ancestral Calculus Instrument Nepohualtzintzin, in the Learning of Arithmetic for the Basic General Education in Unidad Educativa Ciudad De Ibarra School Period 2019 - 2020
}

\author{
Daniel David Sono Toledo*, Simón Bolívar Batallas Bedón, Adriana Elizabeth Aroca Fárez, \\ Jorge Edmundo Gordón Rogel
}

Facultad de Ingeniería en Ciencias Agropecuarias y Ambientales, Facultad de Educación Ciencia y Tecnología, Universidad Técnica del Norte, Ibarra, Av. 17 de Julio, 5-21 y Gral. José María Cordova, Ecuador

Received March 9, 2020; Revised May 6, 2020; Accepted January 25, 2021

\section{Cite This Paper in the following Citation Styles}

(a): [1] Daniel David Sono Toledo, Simón Bolivar Batallas Bedón, Adriana Elizabeth Aroca Fárez, Jorge Edmundo Gordón Rogel , "Development of the Logical Mathematical Reasoning through the Ancestral Calculus Instrument Nepohualtzintzin, in the Learning of Arithmetic for the Basic General Education in Unidad Educativa Ciudad De Ibarra School Period 2019 - 2020," Universal Journal of Educational Research, Vol. 9, No. 4, pp. 757 - 764, 2021. DOI: 10.13189/ujer.2021.090407.

(b): Daniel David Sono Toledo, Simón Bolivar Batallas Bedón, Adriana Elizabeth Aroca Fárez, Jorge Edmundo Gordón Rogel (2021). Development of the Logical Mathematical Reasoning through the Ancestral Calculus Instrument Nepohualtzintzin, in the Learning of Arithmetic for the Basic General Education in Unidad Educativa Ciudad De Ibarra School Period 2019 - 2020. Universal Journal of Educational Research, 9(4), 757 - 764. DOI: 10.13189/ujer.2021.090407.

Copyright $\bigcirc 2021$ by authors, all rights reserved. Authors agree that this article remains permanently open access under the terms of the Creative Commons Attribution License 4.0 International License

\begin{abstract}
This paper addresses the use of Ethnomathematics in the teaching of Mathematics that takes place in the fifth year of Basic General Education and welcomes schoolchildren aged 8-9, according to Ecuadorian educational processes, and explores the logical mathematical development, by teaching arithmetic with the Nepohualtzintzin. The aim is to analyze the quality of learning through the performance of mathematical logical thinking, through the didactic use of the Nepohualtzintzin as an ancestral calculation instrument in students at these ages. Dimensions are based on the development of mathematical logical thinking from pedagogy and psychology. The Nepohualtzintzinwas used by renowned cultures in world history such as the Mayans and Aztecs. Its didactic qualities determine the ease with which students learn the place value of the basic element figures for the resolution of arithmetic operations. Furthermore, the cultural connotation of Ethnomathematics in the
\end{abstract}

didactics of mathematics is also established. An exploratory, documentary, descriptive and longitudinal study is described. Pretest and posttest were applied, which were statistically processed with the SPSS package. The analysis carried out allows indorsing the feasibility of the proposal for the development of mathematical logical thinking through the determined dimensions. In end of this study, significant positive results were identified among the experimental group with respect to the control group, all of which ratifies the importance of the study.

Keywords Nepohualtzintzin, Didactics, Mathematics, Learning

\section{Introduction}

Mayan and Inca Civilization had their 
prehispanicdomain over Meso-America and South America respectively. Unfortunately, almost all their mathematical knowledge remained in history. Two of them have been specially the arithmetic calculus instruments that arrive to the present day, the Nepohualtzintzin from the Mayans, and the Yupana from the Incas; abacus which gave signs of their undeniable wisdom.

With respect to this, it is necessary to point out that Ethnomathematics is a discipline from Educative Mathematic which is enriched from diverse fields, such as the historic, philosophic, geographic and the anthropologic. It is oriented to contextualize multiculturally the teaching processes - mathematics learning and to establish links between culture, math, history, geography, anthropology and other social sciences.

Thereby D'Ambrosio (1988) cited in Suárez, Acevedo, and Huertas [24] (2009), points out that: "we call Ethnomathematics to the art or technique of understanding, explanation, learning about, contention and handling of the natural, social and political environment, depending on the processes such as counting, measuring, classifying, organizing, inferring which result from well identified cultural groups".

To Gavarrate (2012) cited in Vásquez and Trigueros [26] (2015), they point out that Ethnomathematics application tries to characterize the mathematic cultural knowledge from some indigenous groups, thence the importance in the teacher's formation for this ethic contexts. Thus, it unveils their potentialities to study the origin, evolution, and applicability of arithmetic calculus instruments such as the Nepohualtzintzin and the Yupana. They contribute to preserving the cultural and patrimonial values from our cultures, in addition to use them as instrument to potentiate the learners' learning with the own Mathematics' development.

In such sense, the potentiality of using historical context from mathematic results is interesting for approaching this science's problems. In this sense, Huapaya \& Salas [5] (2008) propound: “. ... it is important to highlight that; as teachers we must find connections between Ethnomathematics and our history, presenting a mathematics' teaching integrated inside history and culture. This will imply a pedagogical and didactical advantage at achieving the study objects to have reality in other subject's contexts. In this way we can enrich our strategies' repertory and design didactical situations oriented to improve the conceptual comprehension of Geometry topics in the first year of Secondary Education" (p. 7)

The current research is based on the study in the usage of Ethnomathematics applied to teaching, approaching from an associative focus, which involves the ancestralism with the modernism; is justly to insist on new didactical methodologies that penetrate in the scholar curriculums, to counteract the deficiency of mathematical learning, and therefore help the logical-mathematical development.

It is posed as objective to analyse the learning quality through the logical-mathematical thinking performance, throughout the didactic usage of Nepohualtzintzin as an ancestral instrument of arithmetic calculus in 8-9 years old schoolchildren.

The study is intentionally developed in the fifth year of Basic General Education, according to the educative Ecuadorian processes, and explores the logical-mathematical development, through arithmetic teaching with the Nepohualtzintzin.

\section{Theoretical Framework}

\section{The Nepohualtzintzin as ancestral calculus tool}

The authors López and López [8] (2014), define Mesoamerica as a cultural super area, integrated by diverse societies, in where their good exchange relationships, human mobility, governance common interests among them, and constant wars for a particular dominance, determine their historical context since the $2500 \mathrm{BC}$ until $1521 \mathrm{AD}$.

According to Díaz Infante (1984), cited in Rojas [18] (2005), Aztec education was guided under educative techniques, among which were highlighted: "Advice and persuasion, the method was essentially nontechnique: the message repeats once and once again, reinforcing, to stay registered better in memory; audio-visual education, with ideograms, griffins, oral tradition, music and dance" ( $p$. 159).

Surely education shored up in these techniques, although, it should have lied on manual instruments such as the Nepohualtzintzin "this is because of the fact that its manipulation requires to take a natural mental active process, which stimulates not only calculus, but also memory and abstraction skills, very differently than memorizing multiplication tables" (Ramírez [14], 2009)

In a previous work from the author, Sono [23] (2019) there are described the fundaments of Nepohualtzintzin as calculus instrument and its use for solving basic arithmetic operations. It is demonstrated its operability and how the system is adapted perfectly to the current numbers' writing. It is vital for the current work the methodologic strategy that leads how to prepare teachers to usage inside Mathematics teaching.

In the cited work there are boarded criteria that favours the logical-mathematical thinking development such as organization, data analysis in a systematic way to solve problems, the verification of strategies to solve problems, prove and interpret results and generalize solutions: the usage of representation forms, the realizations of estimations and anticipation, measuring results and in arithmetic operations, among others.

\section{Childhood and its mathematical logical development}

According to Piaget [13] (2000), cognitive development begins when the boy or girl assimilates those things from the environment that surrounds them with reality to their 
own structures, so that before starting formal schooling, most of them acquire considerable knowledge about counting, number and arithmetic.

Children between 8 and 9 years old, which is the competent case of the study, are considered as schoolchildren (García M., 2003), the age at which they can "understand mental representations of others" (Ríos\&Florez [15], [16], 2017, p. 31); since they have adult characteristics (size, strength, and delicacy); their hands are more refined, which improves fine motor skills; there is also openness to the use of reason.

According to Mesonero [9] (1995), in his work Psicología del desarrollo y de la educaciónen la edad escolar, he points out that in this period there are eight the types of "mental operations" with which gets the child gets familiar: Classes Hierarchy, gradual ordering of differences, substitution, symmetric or reciprocal relations, classes and series multiplication, establishment of inverse relations and the genealogical tree of classes.

This author also adds: "In this stage of thought it is modelled by the" logical-mathematical "operations that will make possible the decentration and the consequent understanding of the phenomena of conservation of mass, weight and volume, as well as space, time, and number" (p. 254).

Thinking is a complex act which allows to form series of mental representations to later get an action, to achieve it, it is necessary a set of mental operations such as: identification, ordering, analysis, synthesis, comparation, abstraction, generalization, codification, decoding and classifying among others, thanks to which we can shape these thinking skills denominated logical-mathematical thinking. These are at the same time the ones that lead the student to assimilate the subjects' contents, so that then, he or she could use them in the required moment.

There exist diverse ways of stimulating the logical-mathematical thinking, amongst them there are the employment of diverse games, the making of activities to compare and classify, the propounding of problems that involve challenges and mental effort, quantities manipulation, among others. In our case we will propose the utilization of Nepohualtzintzin because it can integrate several of the indicated forms in didactical activities developed with the students.

\section{Methodology}

\section{Type of Investigation}

The study focuses on the paradigm of quantitative research. It has an exploratory investigative scope since there is little background and very little information on the topic addressed, in addition to its scope of study it is characterized as experimental and longitudinal in nature due to the school period of classes, which corresponds to September 2018 to July of 2019, in which the Nepohualtzintzin was used as a teaching medium.
(Hernández, Fernández, \& Baptista [4], 2014).

The research design is quasi-experimental because it is considered that it is not possible to carry out the random selection of the participating subjects, and it is not possible to have absolute control of the situations (Segura [21], 2003); on the other hand, the hypotheses are located within a group difference attributing causality (Hernández, Fernández, \& Baptista [4], 2014).

\section{Investigation Methods}

The inductive method has favoured this research, since its study field starts in an observation process of enough events to understand its common features, and explain somehow its behaviour. Its employment allows to start from the results analysis understood as a whole, to then decompose it in more critical arguments. (Palella\& Martins [12], 2012)

\section{Techniques and investigation instruments}

Tests were used before and after the intervention, which constituted instruments that enabled the obtaining of relevant information for the study, were constructed, according to the status of the curricular block in Mathematics, according to the textbook issued by the Ecuador Ministerio de Educación [10], (2016).

Observation was used as complementary techniques to the study, to know in the classroom the behaviour of the students during the intervention. The contents register and the study of documents were used. (Hernández, Fernández, \& Baptista [4], 2014).

As an intervention instrument, the Nepohualtzintzin was used for the development of training activities both at scale for the use of the teacher, and for individual manipulation of the students. Bibliographic files were used for knowledge management and the APA 7th Edition standard was used. (American Psychological Association [1], 2020)

The instruments are content records (content analysis) and the tests themselves, which were processed in the SPSS application (Statistical Package for the Social Sciences) in version 20 .

\section{Population}

Population is acquiesced by the fifth-grade students of BGE from Unidad Educativa "Ciudad de Ibarra", part of the Ibarra Canton, Imbabura Province in Ecuador in years 2019-2020.

\section{Data Processing}

The data were processed in SPSS version 22.0, to obtain the methodologically proposed correlation; the presentation of tables follows the APA standard. Its discussion is approached under scientific argumentation.

\section{Analysis and Results Discussion}




\section{Educative intervention}

The employment of Nepohualtzintzin in Mathematic classes as the mean for logical-mathematical thinking development suited to the procedures given by the Secretaría de EducaciónPúblicafrom México [22](SEP, 2009) and the methodological preparation of the teachers was procured. Sono [23] (2019). The intervention was carried out during the period 2019-2020.

\section{Pre and posttest results analysis for the experimental and control groups}

Table 1. Dimensions' organization by groups and test

\begin{tabular}{|c|c|c|c|}
\hline $\begin{array}{l}\text { INITIAL } \\
\text { TEST }\end{array}$ & $\begin{array}{l}\text { Experimental } \\
\text { group }\left(\mathrm{YO}_{1}\right)\end{array}$ & $\begin{array}{l}\text { EXIT } \\
\text { TEST }\end{array}$ & $\begin{array}{c}\text { Control } \\
\text { group }\left(\mathrm{YO}_{2}\right)\end{array}$ \\
\hline \multicolumn{2}{|c|}{$\begin{array}{l}\text { Operability } \\
\text { Analysis } \\
\text { Synthesis } \\
\text { Mathematical objects } \\
\text { handling }\end{array}$} & \multicolumn{2}{|c|}{$\begin{array}{ll}- & \text { Operability } \\
- & \text { Analysis } \\
- & \text { Synthesis } \\
- & \text { Mathematical objects } \\
& \text { handling }\end{array}$} \\
\hline
\end{tabular}
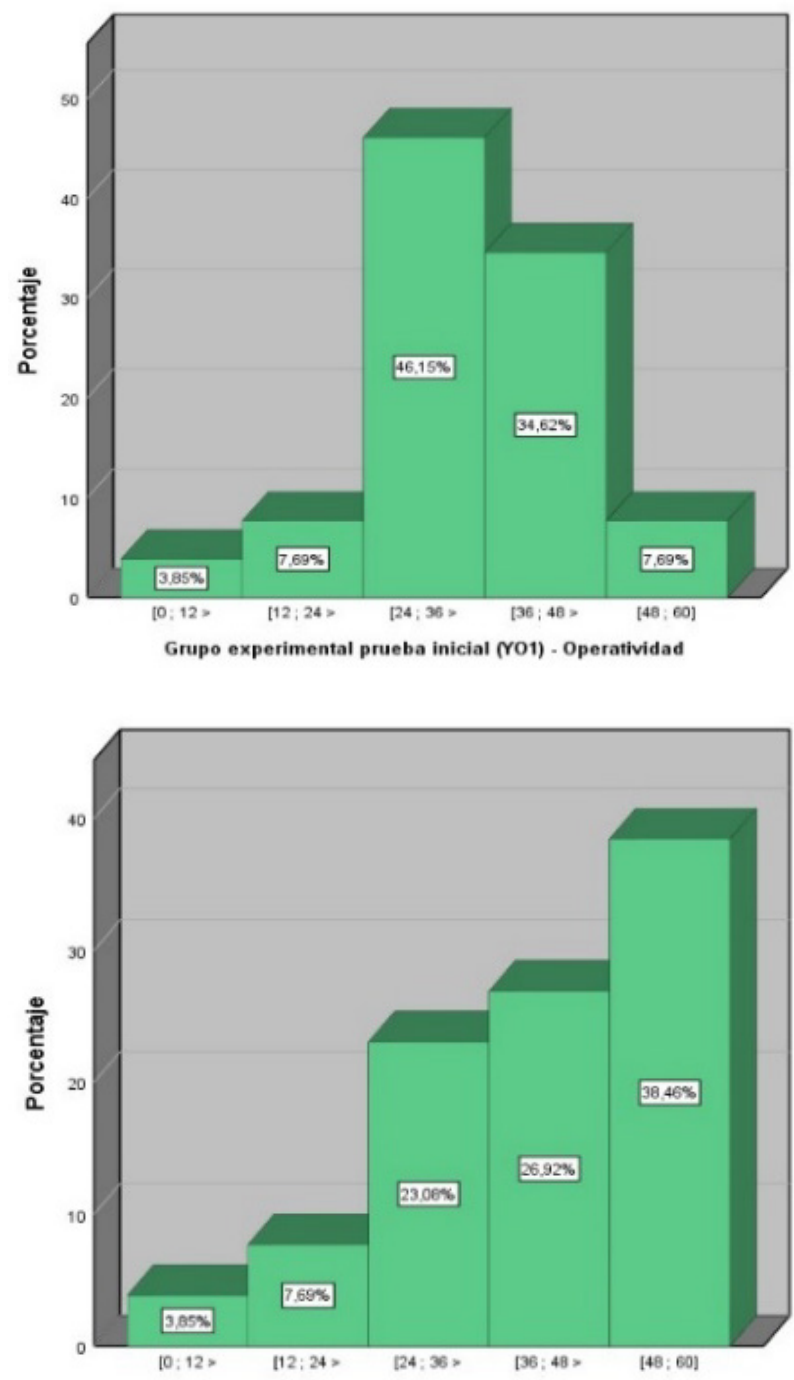

Grupo experimental prueba de salida (Y03) - Operatividad

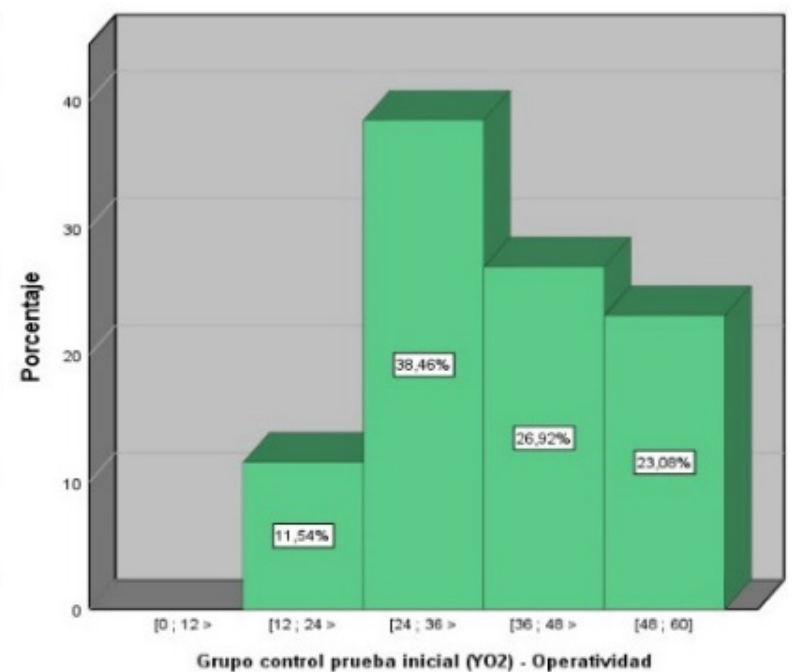

Grupo control prueba inicial (roz) - Operatividad

In the next section, there are presented the kept process and the obtained results in pre-test and post-test, evaluating the 26 cases that made up the sample, organized by dimensions which are presented in the table 1.

\section{Dimension: Operability}

The graph illustrates the results obtained in the initial and final tests for the Operability Dimension in the experimental group and in the control group. The significant differences that are reached before and after the pedagogical intervention can be observed in the group that used, in mathematics teaching, the Nepohualtzintzin for the development of mathematical logical thinking. In the initial test histogram of the experimental group, most of the cases are in the frequency's interval $[24 ; 36>$ with $46.15 \%$, as the mean is 36.35 , it also has a standard deviation of 10.729 . Consequently, it has a coefficient of variation of $30 \%$, this indicates a relative homogeneity of the data.

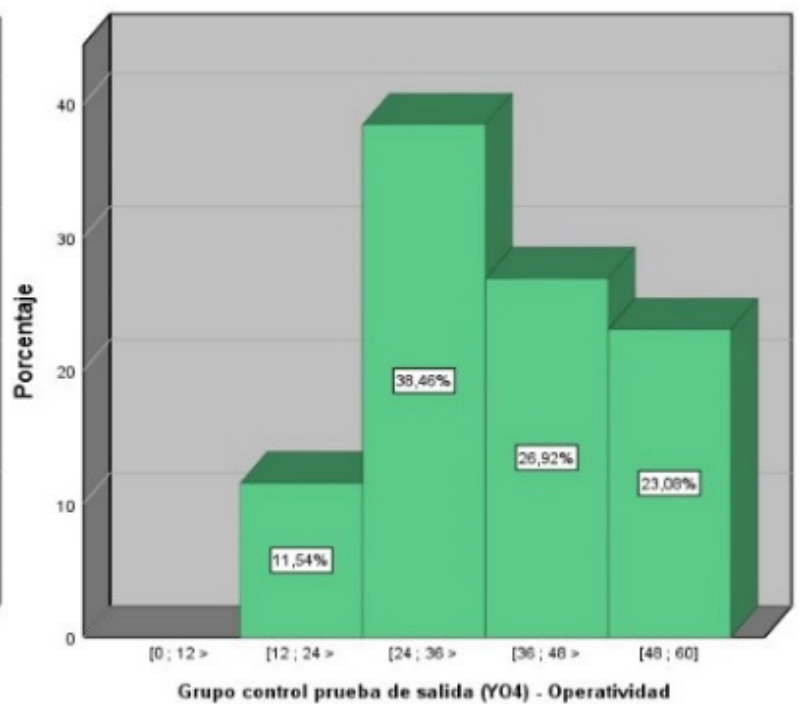

Figure 1. Results of Operability dimension for pre and posttest per groups 
While in the exit test from this group, we can see that most of the evaluated cases are in the range of $[48 ; 60]$ with $38.46 \%$ of frequencies. It can be seen that the mean is 42.5 with a standard deviation of 14,634 , and this leads to a variation coefficient of $34 \%$, which indicates a relative homogeneity of the evaluated data.

The results are contrasted in the control group, where there is homogeneity in the pre- and post-test results where Nepohualtzintzin was not used. Therefore, it can be concluded that there are significant differences in the results when the Nepohualtzintzin is used in the teaching of Mathematics, which shows the development of the Operability dimension.

\section{Dimension: Analysis}

In the initial test histogram in Analysis dimension of the experimental group, we can see that most of the cases are in the interval $[48 ; 60]$ with $42.31 \%$ in that range. It can also be seen that the mean is 44.04 , and has a standard deviation of 9,594; this leads to a $22 \%$ coefficient of variation (CV), which indicates a relative homogeneity of the data. In the
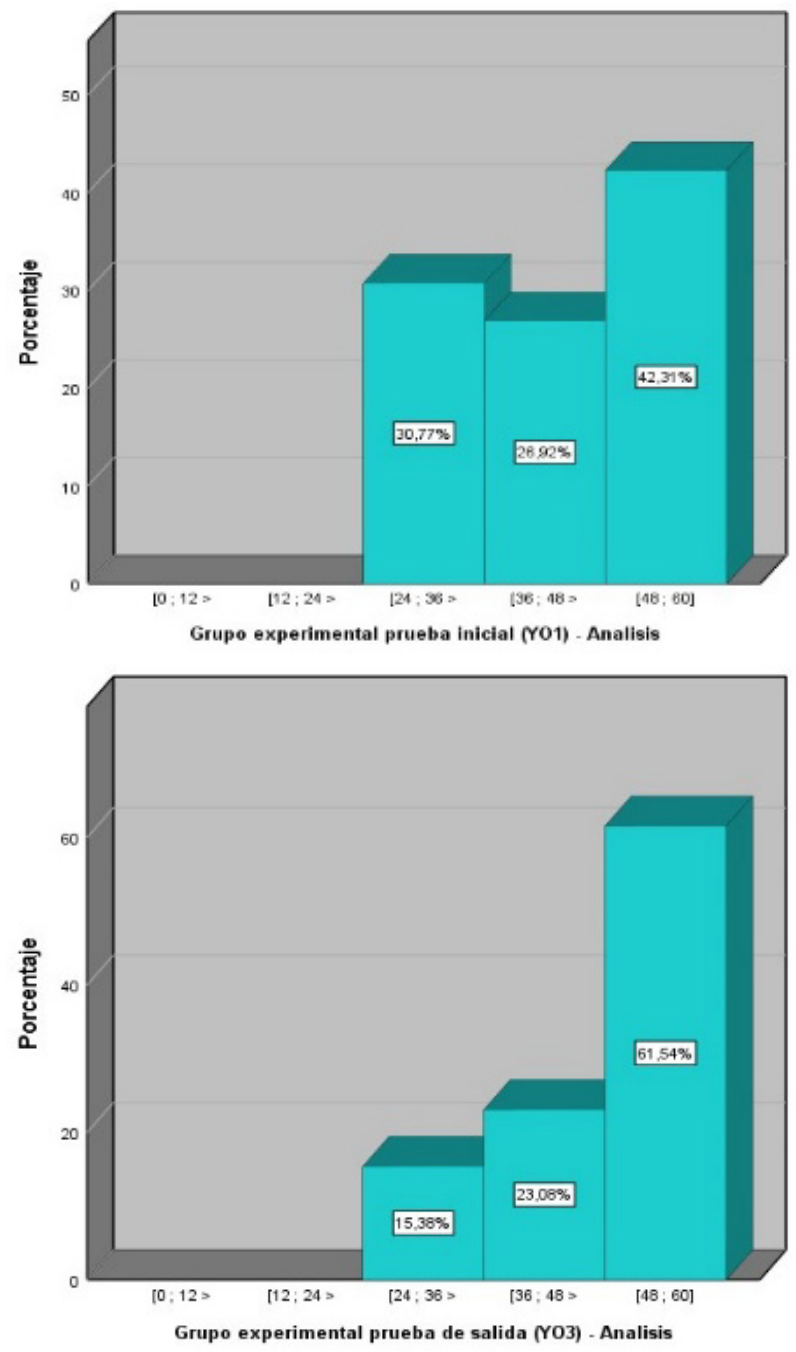

frequencies of the Analysis dimension of the experimental group we can see that a large part of the cases are in the interval $[48 ; 60]$ having $61.54 \%$ of the total cases, continuing with the statistics. Moreover, it can be noted that the mean is 50.58 , also has a standard deviation of 10,424 , with a coefficient of variation of $21 \%$, which leads to assessing a relative homogeneity of the data.

In the control group's initial test, it is noted at first glance that most of the evaluated cases are in the range of $[24 ; 36>$ with $38.46 \%$, in the same way it can be seen that the mean is 39.23 with a standard deviation of 10,459 , and a coefficient of variation of $27 \%$, this denotes a relative homogeneity of the evaluated data. While, in the final test, the highest percentages of the frequencies are in the interval [ $36 ; 48>$ and it has $38.46 \%$ of the total frequencies. It is concluded again that there are significant differences between the results achieved in the control groups, when the Nepohualtzintzin is applied in the teaching of Mathematics, which validates its use as mean for the development of mathematical logical thinking in the Analysis dimension.
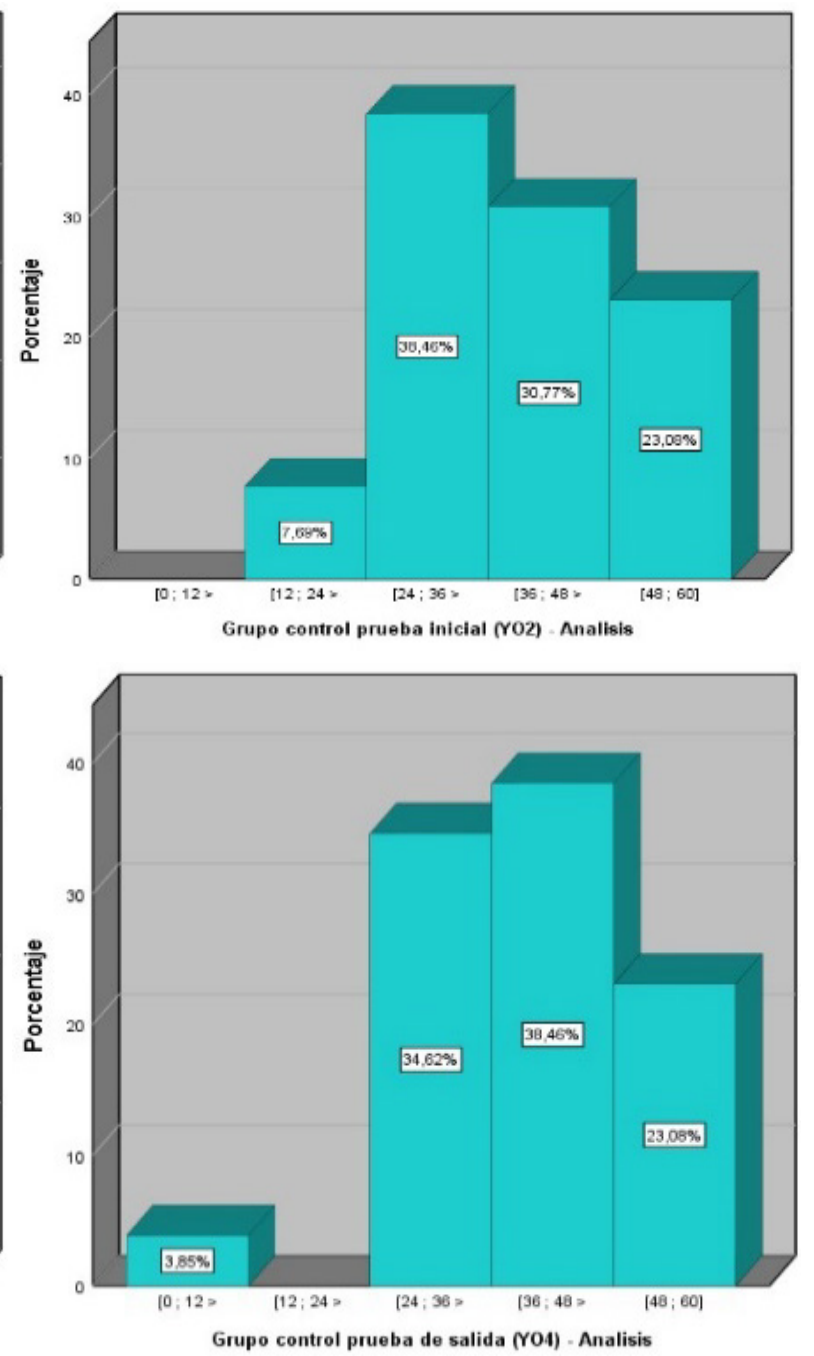

Figure 2. Results of Analysis dimension for pre and posttest per groups. 


\section{Dimension: Synthesis}

Regarding the Synthesis dimension, the experimental group histogram shows that the frequencies, from the dimension in the initial test, are mainly centred in the interval $[24 ; 36>$ since it has $34.62 \%$ of cases accumulated here. In like manner, it is exposed that the mean is 40.77 with a standard deviation of 10.648 . Therefore, it has a coefficient of variation of $26 \%$, which denotes a relative homogeneity of the evaluated data. In the results of the final test we can see that most of the cases are in the interval $[48 ; 60]$ with $50 \%$, it can also be noted that the mean is 47.12 with a standard deviation of 12.097 , and a coefficient of variation (CV) $26 \%$, revealing a relative homogeneity of the evaluated data. For the experimental group, greater results can be inferred when the Nepohualtzintzin is used for the development of the Synthesis as a dimension of mathematical logical thinking.

In the initial test of the control group, it can be seen that a large part of the cases are in the interval $[36 ; 48>$ and have $42.31 \%$ in that range, in the same way it can be seen that the mean is 41.54 , while in the final test, it is noted with the naked eye that most of the cases evaluated are in the range [24; 36> with $42.31 \%$ and decrease towards the higher scales. If we compare the results in the control group, positive changes can be observed in the results, but they are not widely significant compared to the experimental group. Anyway, it allows to validate the proposal when it is used in the Mathematics teaching.
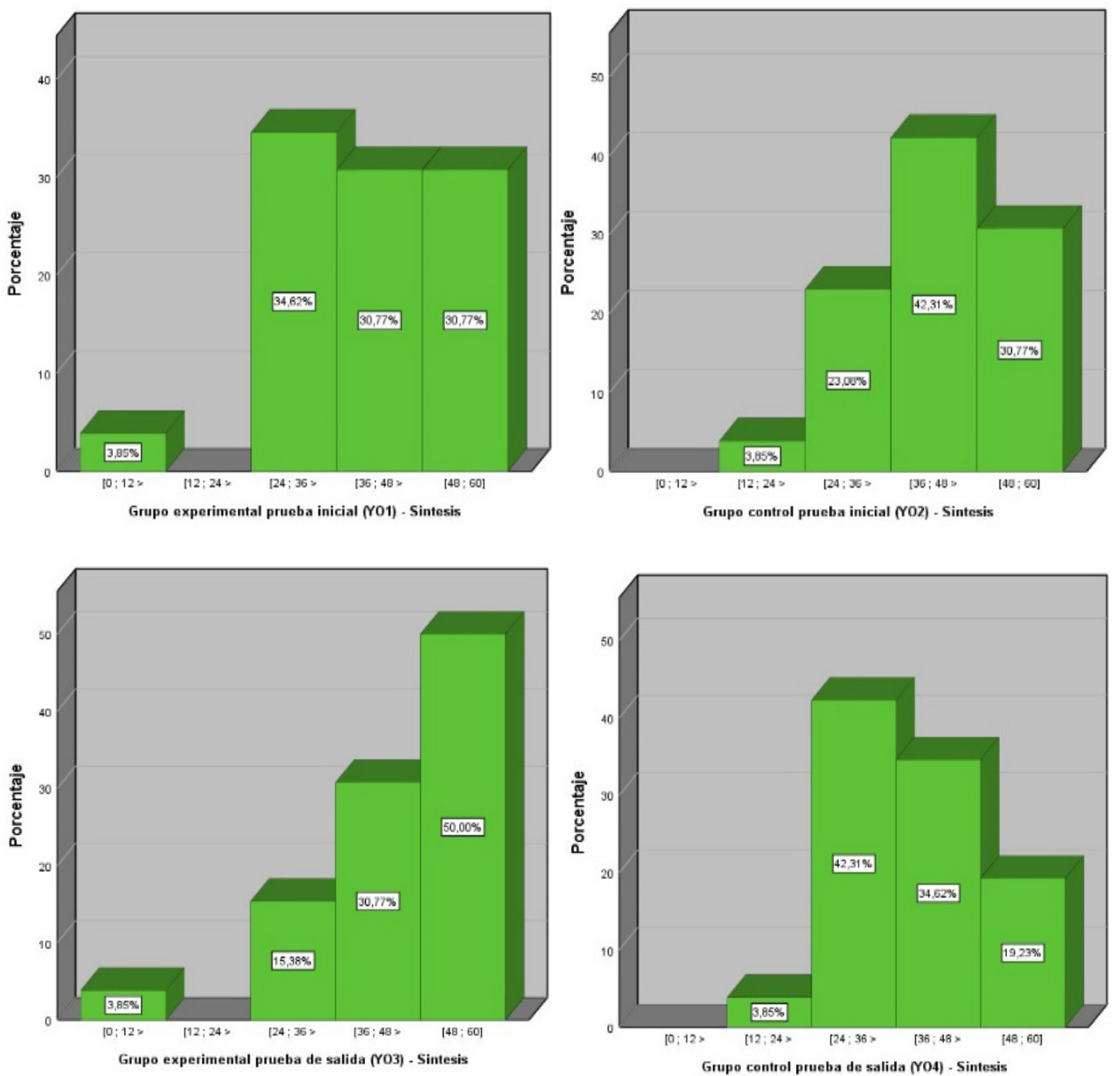

Figure 3. Results of the Synthesis dimension for the pre and posttest by groups 

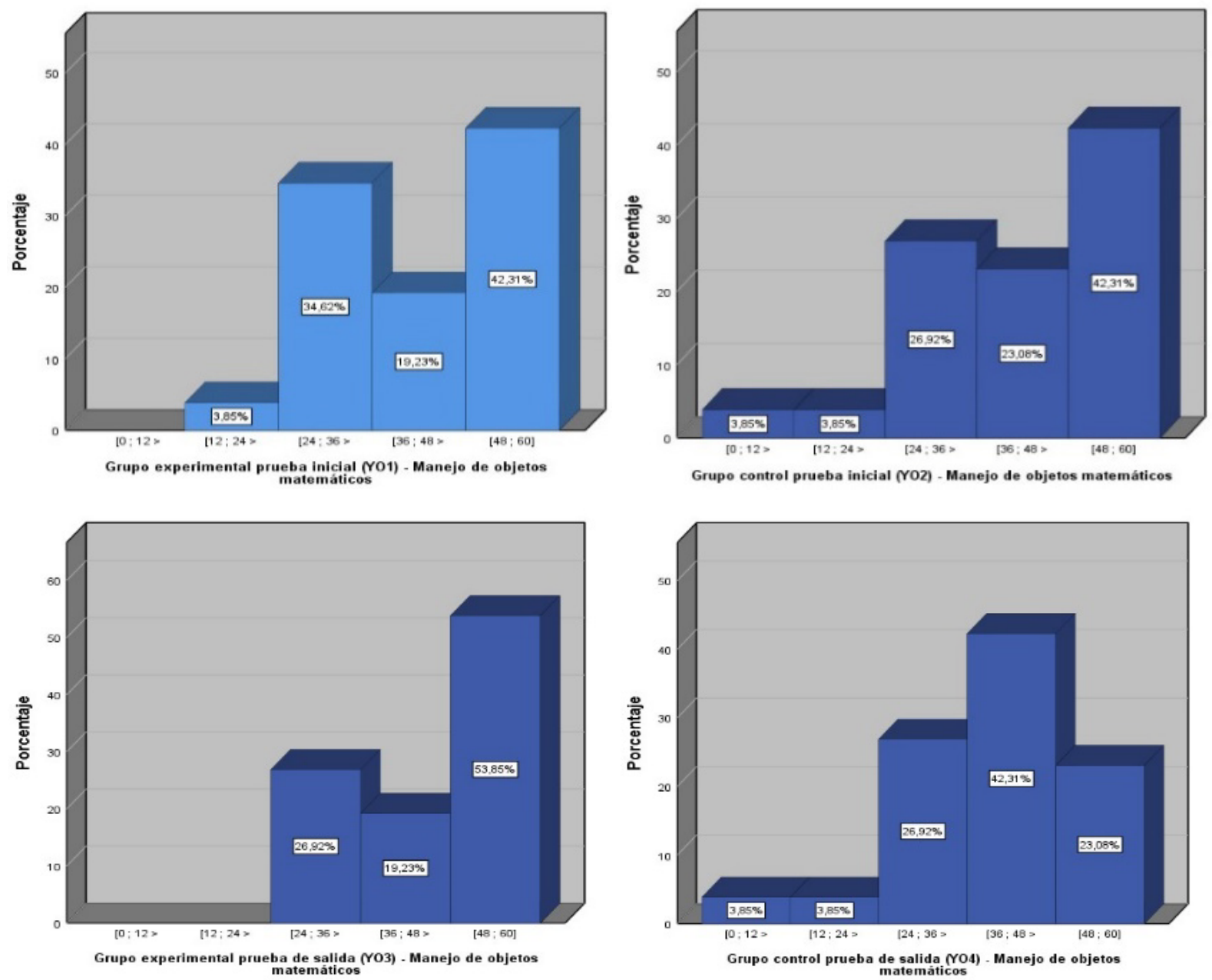

Figure 4. Results of the Mathematical Objects Handling dimension by groups

\section{Dimension: Mathematical objects handling}

The histogram of the dimension, Handling of mathematical objects, shows the initial test results, so it was possible to know that in the experimental group most of the cases are in the interval $[48 ; 60]$ since it has $42.31 \%$ In this range, continuing with the statistics, it can be seen that the mean is 43.27 with a standard deviation of 13,337 , which leads to a $31 \%$ coefficient of variation $(\mathrm{CV})$. In the exit test, most of the cases are in the interval $[48 ; 60]$ with $53.85 \%$ in that range, as well it can be seen that the mean is 47.88 with a standard deviation of 12.097 , and a coefficient of variation of $25 \%$, highlighting a relative homogeneity of the data. Finally, it can be known that there is a grouping of the results towards the scales with the best results and that they increase by an accepted percent. The feasibility of the proposal for the development of logical-mathematical thinking through the Mathematical Objects Handling dimension is undeniable.

\section{Conclusions}

The use of Ethnomathematics in mathematics teaching constitutes a need supported by its potentialities around the integration of knowledge of this discipline and its link with history. It contributes to safeguarding the cultural heritage of indigenous people through the integration of instructive, educational and attitudinal knowledge.

Dimensions were determined to stimulate mathematical logical thinking by using Nepohualtzintzin in mathematics classes from pedagogical and psychological conceptions of the students under this study.

For the implementation of the Nepohualtzintzin in mathematics teaching, a quasi-experiment was applied with fifth grade BGE students from the Unidad Educativa "Ciudad de Ibarra" part of Canton of Ibarra, Imbabura Province in Ecuador in the year 2019 - 2020, the carried-out analysis allows to support the feasibility of the proposal for the development of mathematical logical thinking through the determined dimensions, significant results were identified, at the end of it, between the experimental group with respect to the control group.

The results achieved allow new opening research lines to study other instruments of ancestral calculation from Ethnomathematics in mathematics learning in the Basic General Education. 


\section{REFERENCES}

[1] American Psychological Association. (2020). Publication manual of the American Psychological Association (7th ed.). https://doi.org/10.1037/0000165-000 Cuadernos de Psicología

[2] García, M. (2003). Peculiaridades del Paciente Pediátrico. Retrieved on October 6, 2019, fromhttps://tinyurl.com/y3sc ohqn

[3] Gavarrete, M. (2013). La Etnomatemática como campo de investigación y acción didáctica: su evolución y recursos para la formación de profesores desde la equidad. Revista Latinoamericana de Etnomatemática, VI(1), 127- 149. Retrieved on September 26, 2017, from http://www.redalyc .org/articulo.oa? $\mathrm{id}=274025755006$

[4] Hernández, R., Fernández, C., \& Baptista, P. (2014). Metodología de la investigación. México: Mcgraw-hill / interamericana editores, s.a. de c.v.

[5] Huapaya, E., \& Salas, C. (2008). Uso de las Ideas Matemáticas y Científicas de los Incas, en la Enseñanza Aprendizaje de la Geometría. Revista Latinoamericana de Etnomatemática, 4-11. Retrieved on November 24, 2019, from https://tinyurl.com/v6nermr

[6] Lara, E., \& Lara, J. (2014). Nepohualtzintzin: un modelo matemático náhuatl. revista digital universitaria, 1-14. Obtained from http://www.revista.unam.mx/vol.15/num2/ar t09/

[7] Lara, E., \& Sgreccia, N. (2010). Nepohualtzintzin: un modelo matemático de cualidad. Revista Latinoamericana de Etnomatemática, 24-54. Retrieved on November 29, 2019, from https://tinyurl.com/ud3ejta

[8] López, A., \& López, L. (2014). La periodización de la historia mesoamericana. ARQUEOLOGÍA MEXICANA, 14-22. Retrieved on September 25, 2017, from http://www.mesoweb.com/about/articles/AM043.pdf

[9] Mesonero, A. (1995). Psicología del desarrollo y de la educación en la edad escolar. Retrieved on October 6, 2019, from https://tinyurl.com/y2nwo9pz

[10] Ministerio de Educación. (2016). Matemática $5^{\circ}$ grado Texto del estudiante. Retrieved on October 31, 2019, from https://tinyurl.com/y6gpr9v3

[11] Ministerio de Educación. (2016e). Talento matemático 2. Quito: Edinun.

[12] Palella, S., \& Martins, F. (2012). Metodología de la Investigación. Segunda Edición. Caracas, Venezuela: Fondo Editorial de la Universidad Pedagógica Experimental Libertador, UPEL-FEDUPEL.

[13] Piaget. J. (2000) Aportaciones del padre de la Psicología Genética. México:
[14] Ramírez, F. (2009). Galería de Misterios. Retrieved on September 25, 2017, from https://sites.google.com/site/gale riademisterios/home/la-calculadora-azteca

[15] Ríos, J. (2013). Las matemáticas ancestrales y la yupana. Pensamientopedagógico, 41-47. Retrieved on November 27, 2019, from https://tinyurl.com/sa367p7

[16] Ríos, J., \& Florez, E. (2017). Teoría de la mente en niños de 6 a 10 años de edad con antecedente de nacimiento prematuro y en edad escolar. Psychologia, 29-43. doi: $10.21500 / 19002386.2626$

[17] Rivero, M. (2012). Teoría genética de Piaget. Retrieved on November 23, 2019, from https://tinyurl.com/uczj98m

[18] Rojas, O. (2005). La educación entre los aztecas. Ethos Educativo, 154-160. Retrieved on September 25, 2017, from http://www.imced.edu.mx/portal/files/EthosWeb/Archivo/3 3-34-154.pdf

[19] Sánchez Regalado, P. (2001-2006). Los Ábacos Instrumentos Didácticos. México: Programa Nacional de Educación México.

[20] Santillán, A., \& Zachman, P. (2009). Una experiencia de capacitación en Etnomatemática. Revista Latinoamericana de Etnomatemática, 27-42. Retrieved on November 24, 2019, from https://tinyurl.com/rywbt99

[21] Segura, A. (7 de 2003). Diseños cuasiexperimentales. Obtained from StudyLib:https://studylib.es/doc/5577858/lo s-dise $\% \mathrm{C} 3 \% \mathrm{~B} 1$ os-cuasiexperimentales-son-una-derivaci $\%$ C3\%B3n-de-los

[22] SEP. (2009). Manual didáctico del Nepohualtzintzin para el desarrollo de competencias matemáticas. Ciudad de México: Secretaría de Educación Pública.

[23] Sono, D. (2019). El Nepohualtzintzin: instrumento de cálculo ancestral y su aplicación en la enseñanza de las operaciones aritméticas básicas. RevistaConrado, 410-418. Retrieved on November 27, 2019, https://conrado.ucf.edu.c u/index.php/conrado/article/view/1094/1103

[24] Suárez, M., Acevedo, M., \& Huertas, C. (2009). Etnomatemática, educación matemática e invidencia. Revista Latinoamericana de Etnomatemática, 17-51. Retrieved on November 23, 2019, from https://tinyurl.com/ w5sqkbs

[25] Tejón, F. (2009). Manual de uso del ábaco vigesimal Nepohualtzintzin.Retrieved on November 29, 2019, from https://tinyurl.com/wmmqyno

[26] Vásquez, A., \& Trigueros, E. (2015). Etnomatemática en Costa Rica: Un acercamiento a su perspectiva sociohistórica. Revista Latinoamericana de Etnomatemática, 69-91. Retrieved on November 23, 2019, from https://tinyurl.com/ vulmdan

[27] Vázquez, Á. (2016). Nepohualtzintzin: una experiencia docente en matemáticas. Retrieved on December 1, 2019, from https://n9.cl/au08 